\title{
Understanding the Relationship between Founder-CEOs and Firm Performance
}

\author{
Renée B. Adams \\ Stockholm School of Economics \\ renee.adams@hhs.se
}

\author{
Heitor Almeida \\ NYU/Stern and NBER \\ halmeida@stern.nyu.edu
}

\author{
Daniel Ferreira \\ Universidade Nova de Lisboa \\ daniel.ferreira@fe.unl.pt
}

(This version: September 9, 2005)

\begin{abstract}
While previous empirical literature has examined the effect of founder-CEOs on firm performance, it has largely ignored the effect of firm performance on founder-CEO status. In this paper, we use instrumental variables methods to better understand the relationship between founder-CEOs and performance. Using the proportion of the firm's founders that are dead and the number of people who founded the company as instruments for founder-CEO status, we find strong evidence that founder-CEO status is endogenous in performance regressions. After instrumenting for founder-CEO status, we identify a positive causal effect of founder-CEOs on firm performance which is quantitatively larger than the effect estimated through standard OLS regressions. Contrary to the common perception that founder-CEOs will retain their titles following good performance, we show that performance is negatively related to the likelihood that founders retain the CEO title. This result appears to be driven primarily by founder departures after periods of good performance, rather than by an entrenchment effect that allows founders to remain as CEOs following poor performance. We provide several potential explanations for this new finding.
\end{abstract}

\footnotetext{
*We wish to thank Yakov Amihud, David Sraer, Daniel Wolfenzon, and seminar participants at the CEPR/ECGI/INSEAD/NBER/University of Alberta joint conference on "The Evolution of Corporate Governance and Family Firms" at INSEAD, the 2004 European Meeting of the Econometric Society, and the 2004 Istanbul Conference on "Family Firms and Corporate Governance" for comments and suggestions. We also thank Victoria Ivashina, Kabir Kochnar, Michael Rodriguez and Adrienne Rumble for excellent research assistance. All remaining errors are our own. Corresponding author: Heitor Almeida, 40 West 4th Street room 9-190, New York NY 10012.
} 


\title{
Understanding the Relationship between Founder-CEOs and Firm Performance
}

(This version: September 9, 2005)

\begin{abstract}
While previous empirical literature has examined the effect of founder-CEOs on firm performance, it has largely ignored the effect of firm performance on founder-CEO status. In this paper, we use instrumental variables methods to better understand the relationship between founder-CEOs and performance. Using the proportion of the firm's founders that are dead and the number of people who founded the company as instruments for founder-CEO status, we find strong evidence that founder-CEO status is endogenous in performance regressions. After instrumenting for founder-CEO status, we identify a positive causal effect of founder-CEOs on firm performance which is quantitatively larger than the effect estimated through standard OLS regressions. Contrary to the common perception that founder-CEOs will retain their titles following good performance, we show that performance is negatively related to the likelihood that founders retain the CEO title. This result appears to be driven primarily by founder departures after periods of good performance, rather than by an entrenchment effect that allows founders to remain as CEOs following poor performance. We provide several potential explanations for this new finding.
\end{abstract}




\section{Introduction}

Founders have unique relationships with their firms. Because of their privileged position, founders may be able to extract higher private benefits of control. Founder-CEOs might also distort investment decisions because they are not well-diversified. As firms evolve, founders may no longer have the necessary expertise to run their companies (Wasserman, 2003), but they may be unwilling to relinquish control (Shleifer and Vishny, 1989). When they do give up control, they may have a preference for passing it on to potentially underqualified family members (Pérez-González, 2002). On the other hand, their incentives might be more aligned with outside shareholders than those of professional managers, not only because founders usually have high ownership stakes, but also because they might have longer investment horizons (Stein, 1989). Because they care about their firms, they may exert more effort for a given incentive structure (Palia and Ravid, 2002).

These arguments suggest that the relationship between firm performance and founderCEO status is different than it is for professional managers. Not only may firm performance be different when the founder is in charge, but performance may also affect founder-CEO turnover in a different manner than it affects the turnover of professional CEOs. Previous empirical literature has examined the effect of founder-CEOs on firm performance. Management studies report a positive correlation, a negative effect, or no effect (Jayaraman et al., 2000). In the finance literature, Morck, Shleifer, and Vishny (1988), McConaughy et al (1998), Palia and Ravid (2002), Anderson and Reeb (2003), Fahlenbrach (2005), and Villalonga and Amit (2005) report a positive effect of founder-CEOs on performance. However, these studies largely ignore the effect of firm performance on founder-CEO turnover. ${ }^{1}$ There are good reasons to expect the founder-CEO status to be a function of firm performance. For example, because CEOs appear to retain their titles more frequently when the firm is doing well (Warner, Watts and Wruck, 1988; Weisbach, 1988; Jensen and Murphy, 1990), this might also be true for founders. On the other hand, if founders are entrenched then it might be difficult to remove them, even following poor performance. This entrenchment effect could bias the coefficient on founder-CEO status downward in performance regressions.

In this paper, we attempt to understand the exact nature of the relationship between

\footnotetext{
${ }^{1}$ Anderson and Reeb (2003) and Villalonga and Amit (2005) use idiosyncratic risk and other variables as instruments for family ownership and family control in some regressions, but they do not focus specifically on the founder-CEO variable. In parallel research, Fahlenbrach (2005) develops alternative instruments for the founder-CEO variable, but he does not focus directly on the effect of performance on founder-CEO turnover.
} 
founder-CEOs and performance, by fully incorporating the effect of firm performance on founder-CEO status into the empirical analysis. We use instrumental variables methods to disentangle the effect of founder-CEOs on performance from the effect of performance on founder-CEO status. Our methodology allows us to identify whether founder-CEOs have a positive or negative effect on performance, and whether performance has a positive or negative effect on founder-CEO status.

Our primary sample consists of data on Fortune 500 firms over the 1992-1999 period. Using Tobin's $Q$ and $R O A$ as measures of performance, we confirm the positive correlation between founder-CEO status and firm performance in OLS regressions that was found in some of the previous studies cited above. However, we cannot necessarily infer a causal relationship from this positive correlation. To address the endogeneity problem we need instruments that are correlated with founder-CEO status but are uncorrelated with performance except through variables included in the performance regression.

We use two instruments. The first is the proportion of the firm's founders that are dead. The second is the number of people who founded the company. Using these instruments, we find strong evidence that founder-CEO status is endogenous in performance regressions, which implies that the effect of founder-CEOs cannot be correctly estimated using OLS. However, after instrumenting for founder-CEO status, we still find evidence consistent with a positive causal effect of founder-CEOs on firm performance. This finding corroborates the suggestion that firms led by their founders perform better than other firms.

Perhaps surprisingly, the two-stage least squares regressions suggest that after factoring out the direct effect of founder-CEOs on performance, the remaining correlation between performance and the likelihood that the founder retains the CEO title is negative. Thus better performing firms are less likely to have a founder as the CEO. This novel finding appears to be inconsistent with the general notion that founder-CEOs will retain their titles following good performance.

We provide several possible explanations for this finding. For example, one possibility is that the results are explained by an omitted variable measuring the overall quality of governance: firms with bad governance are more likely to perform badly and to have a founder who is entrenched. Another possibility is that founder-CEOs are more likely to relinquish control following good performance. To shed further light on this issue, we examine the effect of past extreme performances on the likelihood that founders retain the CEO title. We find that both good and bad past performance increase the probability 
that founders step down. Thus we conclude that the negative effect of performance on founder-CEO status appears to be driven primarily by founder departures after periods of good performance, rather than by an entrenchment effect that allows founders to remain as CEOs following poor performance. We conjecture that the effect of good performance on founder-CEO departures might be due either to a "controlled succession" effect (Morck, Shleifer and Vishny, 1989), whereby founders who wish to transfer control to their heirs can accomplish this more easily following good performance, or more simply to the fact that founders leave their companies only when they are in good shape (Wasserman, 2003).

We start in section 2 by discussing related literature. In section 3 we describe our sample, which we use in section 4 to examine OLS regressions of performance on founderCEO status. In section 5, we address the endogeneity of founder-CEO status. Section 6 provides further evidence on the causal relationship from performance to founder-CEO status and section 7 concludes the paper.

\section{Literature Review}

As we already discussed, other papers examine the effect of founder-CEOs on firm performance. None of these papers focuses on the effect of performance on founder-CEO turnover. A different approach is taken by Johnson et al. (1985), who analyze the stock price reaction following the unexpected death of senior corporate executives. ${ }^{2}$ The authors find that, while there is little reaction on average to sudden executive deaths, there is a positive stock price reaction following the sudden death of a corporate founder. Their suggested interpretation for these results is that corporate founders have higher bargaining power when bargaining over employment contracts with shareholders, and thus receive a larger share of profits than do professional managers who succeed the founder.

An additional explanation for the Johnson et al. (1985) findings is suggested by Schwert (1985) - the "founder effect" may be due to the break up of a large control block of stock, increasing the likelihood of future corporate control fights (that generally benefit target shareholders). This idea is also consistent with the results in Slovin and Sushka (1993), who find that the stock price reaction that follows the death of inside blockholders is higher when the deceased executive's equity stake is large. Their result holds irrespective of whether the executive is a CEO or a founder of the firm. In addition, Zingales (1995) reports evidence

\footnotetext{
${ }^{2}$ Notice that because sudden executive deaths are exogenous events, Johnson et al. (1985) cannot examine the effect of performance on the likelihood that a founder retains the CEO title, as we do.
} 
consistent with the idea that the death of an executive who owns a lot of stock changes the strategic value of a vote and increases the premium of voting shares. Thus, the positive stock price reaction found by Johnson et al. (1985) does not preclude the possibility that firms run by founders perform better than other firms. ${ }^{3}$

Our results are also related to the growing literature on family firms. Family firms include those that are controlled by their founders, and also by the founders' families (Burkart, Panunzi, and Shleifer, 2003). Anderson and Reeb (2003) empirically identify a family firm as one in which the founding family either continues to have an ownership stake, or has one of the seats on the board of directors. Their evidence suggests that family firms perform better than non-family firms, both in terms of accounting ( $R O A, R O E)$ and market performance (Tobin's $Q$ ). ${ }^{4}$ Because firms where the $\mathrm{CEO}$ is a founder are by definition family firms, these results are directly related to our results.

However, not all family firms are directly managed by their founders. In fact, previous literature also suggests that not all family firms are good performers. Morck, Strangeland, and Yeung (1998) find a negative correlation between heir control in Canadian firms and firm performance. Pérez-González (2002) also provides evidence that inherited control by a family member is bad for performance. In his sample, ROA falls by approximately $20 \%$ following the transfer of control to a family heir, and there is a negative stock price reaction when control is inherited. These findings raise the possibility that the higher performance of family firms is driven mostly by firms where the current CEO is a founder, a hypothesis which is consistent with the results that we report in this paper, and also with some results in Anderson and Reeb (2003). ${ }^{5}$

The literature examining the effect of performance on the likelihood that a founder retains the title of CEO is considerably more sparse. An exception is Wasserman (2003), who uses a sample of 202 small Internet firms to examine founder-CEO successions. Although his sample is very different from ours, his main findings are consistent with ours. A founderCEO's success in achieving critical milestones such as a successful completion of product development makes it more likely that a founder will relinquish the CEO title. Thus, it may be the case that the best performing companies replace the founder-CEO sooner than

\footnotetext{
${ }^{3}$ In fact, Fahlenbrach (2005) finds that firms managed by founder-CEOs had positive abnormal stock returns in the 1990s.

${ }^{4}$ Consistent with a positive effect of families on performance, Anderson, Mansi, and Reeb (2003) find that family firms face a lower cost of debt than non-family firms.

${ }^{5}$ See also Villalonga and Amit (2005), who classify family firms into several categories and find that family ownership creates value only when the founder serves as the CEO of the family firm or as its Chairman.
} 
the worst performing companies. However, because Wasserman (2003) does not examine the effect of founder-CEOs on performance measures, the interpretation of his results is potentially compromised by an endogeneity problem (i.e., performance is also a function of whether the CEO is a founder of the company or not).

\section{Data Description}

Our primary sample consists of data on publicly traded firms in the 1998 Fortune 500, excluding regulated financial firms and utilities, during 1992-1999 for which data are available on ExecuComp (2000). From Standard and Poor's ExecuComp (2000) we obtain the names of the sample firms' CEOs, CEO ownership and tenure as CEO as well as some financial information. ${ }^{6}$ We gather the remaining financial information from Compustat and the date of the firm's incorporation from Moody's Industrial Manuals (1999), proxy statements and annual reports for fiscal 1998. Our final sample consists of 2,128 complete firm-years of data for 321 firms during the 1992-1999 time period.

Since ExecuComp (2000) does not contain information on whether the CEO is also a founder, we define founderCEO in a given year to be 0 if the firm was incorporated at least 64 years prior to the current year or if the current CEO joined the company at least 4 years after the date of the firm's incorporation. ${ }^{7}$ For the remaining firm-years we checked whether the current CEO was one of the firm's founders in a variety of sources consisting of proxy statements, annual reports and the internet. ${ }^{8}$ We set founderCEO in a given year equal to 1 if any source explicitly named the current $\mathrm{CEO}$ as a founder or the main executive at the time the company began (including when it was spun-off).

\footnotetext{
${ }^{6}$ In ExecuComp the data item containing the proportional ownership of the CEO is often missing if ownership is less than $5 \%$. We therefore calculate it as the ratio of the number of shares owned by the CEO to total shares outstanding after adjusting the number of shares owned by the CEO for stock splits. While ExecuComp (2000) adjusts the total shares outstanding for stock splits it may not adjust CEO ownership (as can be seen in the case of CEO Bill Gates of Microsoft whose mean ownership according to ExecuComp (2000) is 5.5\% during 1992-1999, but whose actual mean ownership is $23.6 \%$ ), however it does include an adjustment factor (Access item: AJEX) that can be used to adjust ownership. After raising this issue with Standard and Poor's, they changed how ExecuComp reports CEO ownership so that it no longer needs to be adjusted for stock splits in the later versions of the data. However, all data pulled from earlier versions still need to be adjusted.

${ }^{7}$ The longest period of time a CEO has been working for his firm in our sample is 59 years. We use 64 years as a cutoff to account for missing data on CEO firm tenure. Since most firms are founded several years prior to the date of incorporation this procedure ensures that we check more CEOs than are likely to be founders.

${ }^{8}$ When we could find the name of the firm's original founders this procedure was straightforward. However, very few proxies, annual reports or company websites disclosed the names of the original founders. We were most successful doing a search with the name of the executive and the word founder using the Google search engine.
} 
We use both a market-based measure of performance for our sample firms, Tobin's $Q$, as well as an accounting measure, $R O A$. We define Tobin's $Q$ to be the ratio of the firm's market value to its book value. The firm's market value is calculated as the book value of assets minus the book value of equity plus the market value of equity. We define $R O A$ to be the ratio of net income before extraordinary items and discontinued operations to its book value of assets.

In Table 1 we present summary statistics concerning select financial variables and CEO characteristics. During our sample period a founder was the CEO at some point for 50 of our sample firms ( $15.6 \%$ of firms). On the whole a founder was the CEO during $11.1 \%$ of firm-years.

\section{The Empirical Correlation between Founder-CEOs and Firm Performance-Ordinary Least Squares Estimates}

As a first step in understanding the relationship between founder-CEO status and firm performance, we check whether the retention of the CEO title by the founder is correlated with firm performance in our sample. Sections 5 and 6 , in which we discuss possible endogeneity problems and causality issues, analyze this relationship in more depth.

Our measures of firm performance are Tobin's $Q$ and $R O A$. We use two benchmark models for performance throughout this paper. The first one postulates that the variable founderCEO might affect performance along with other firm-level characteristics, which are the log of total assets (a proxy for firm size), the log of firm age, a measure of stock return volatility and 2-digit industry dummies (we omit time and firm subscripts, and $y$ is the performance variable):

$$
\begin{aligned}
y= & b_{0}+b_{1} \text { founderCEO }+b_{2} \ln (\text { assets })+b_{3} \ln (\text { firm age })+b_{4} \text { volatility } \\
& + \text { industry dummies }+ \text { time dummies }+u
\end{aligned}
$$

We do not use firm fixed-effects in our specification because our main explanatory variable (founderCEO) varies little over time for a given firm. ${ }^{9}$ To calculate all $t$-statistics,

\footnotetext{
${ }^{9}$ In the context of the ownership literature, Himmelberg, Hubbard and Palia (1999) argue for the use of firm fixed effects in regressions which relate ownership to firm performance. However, Zhou (2001) points out that if the explanatory variable changes slowly over time (as do ownership and, in our case, founderCEO), firm fixed-effect regressions may fail to detect relationships in the data even when they exist. In addition, Fahlenbrach (2005) shows evidence suggesting that the correlation between founder-CEOs and performance is not caused by a firm fixed effect.
} 
we use heteroskedasticity-corrected standard errors. In addition, to account for over-time correlation within the same firm, we cluster observations by firm. ${ }^{10}$

In Table 2, we report the results of regression (1) for the two performance measures. Column I reports the results using $\log Q$ as the performance measure, ${ }^{11}$ and Column III reports the results using $R O A$ as the performance measure. FounderCEO is significantly positively correlated with both $\log Q$ and $R O A$ at the $1 \%$ significance level (the $p$-values are 0.001 and 0.004 , respectively). Of the other three variables, volatility enters with a significant negative sign in both regressions, while firm size and age have significant negative effects only when performance is measured by $R O A$.

Because it is plausible that founderCEO is correlated with CEO characteristics, it is possible that our results reflect a spurious correlation between founder $C E O$ and performance that is due to omitted variables. In our second specification, we therefore include several CEO characteristics in an attempt to correct for this problem. In particular, we identified three obvious candidates for which founderCEO might be considered a good proxy variable. The first is CEO ownership: it is likely that founders hold a disproportionately large fraction of the firm's equity. It is also reasonable to expect that founders would have long tenures in the firm before leaving the CEO position. Finally, the fraction of the CEO's compensation which is based on equity may be correlated with founderCEO because of differing pay-forperformance incentives for founders. Because all three of these variables might also have direct effects on performance, we add them to our original benchmark model to get: ${ }^{12}$

$$
\begin{aligned}
y= & b_{0}+b_{1} \text { founderCEO }+b_{2} \ln (\text { assets })+b_{3} \ln (\text { firm age })+b_{4} \text { volatility } \\
& +b_{5} \text { CEO ownership }+b_{6} \text { CEO tenure }+b_{7} \text { CEO equity pay } \\
& + \text { industry dummies }+ \text { time dummies }+u
\end{aligned}
$$

In Columns II and IV of Table 2, we report the results of regression (2) for the two performance measures. Consistent with omitted variable concerns, we find in both specifications that the coefficients on founderCEO are smaller than those in the previous specifications. However, founderCEO is still significantly positively correlated with $\log Q$ at the $1 \%$ significance level (the $p$-value is exactly 0.01 ) and with $R O A$ at the $10 \%$ significance level (the

\footnotetext{
${ }^{10}$ Alternative procedures to deal with the group correlation problem lead to virtually identical results. For example, both averaging all variables over the 1992-1999 period or running year-by-year cross-section regressions produce estimated effects and standard errors that are very similar to the ones we report.

${ }^{11}$ We chose a log-linear specification for $Q$ due to the fact that $Q$ can never be negative. Using $Q$ instead of $\log Q$ as the dependent variable might therefore generate fitted values that are outside of the range of $Q$.

${ }^{12}$ Following Anderson and Reeb (2003), we use the value of CEOs' annual option pay divided by the sum of salary, bonus and option pay to measure a CEO's equity-based pay.
} 
$p$-value is 0.056). CEO ownership is also significantly positively related to performance, while CEO equity pay is only significant in the $\log Q$ regression. CEO tenure does not have a statistically significant effect on performance.

Taken at face value, what is the economic significance of these results? It is important to note that because we are using a log-linear specification for $Q$, the marginal effect of founder-CEOs on $Q$ varies positively with the level of $Q$. In our sample, the average $Q$ is 2.05. If we take the estimated coefficient on founderCEO from regression (2) as our estimate of the effect of founder-CEOs on $Q$, our results suggest that a firm with an average $Q$ will experience a drop of 0.37 units in $Q$ whenever its CEO is not also one of its founders. This effect is not trivial, but also not too large: it is about one fourth of the sample standard deviation of $Q$.

Our OLS estimates of the effects of founder-CEOs on the different measures of firm performance are also directly comparable to the ones reported by Anderson and Reeb (2003). Using a different sample-selection procedure and different empirical models from the ones we use in this paper, they find that founder-CEOs have a marginal effect on $Q$ of 0.47 units. While our marginal effect for the average firm in our preferred specification is somewhat lower (0.37), our log-linear specification is not directly comparable to theirs, because our estimated marginal effects are not constant. When we re-estimate our preferred model using $Q$ instead of $\log Q$ as the dependent variable, we obtain an estimated marginal effect of 0.52 $(t=2.30 ; p$-value $=0.022)$, which is not statistically different from 0.47 at any reasonable significance level. Although the log-linear specification appears to produce more conservative estimates than the linear specification, we continue to use our log-linear specification for $Q$ because the differences are small. In addition, our maximum likelihood approach in the next sections requires that, conditional on the right-hand side variables, the dependent variable should be normally distributed. This assumption may not be unreasonable for $\log Q$, but it is false by construction for $Q$.

The similarities between our results and the ones found in Anderson and Reeb (2003) also extend to accounting measures of performance. They find that founder-CEOs have a marginal effect on $R O A$ of 3.14 (when $R O A$ is measured using net income, as in this paper), an effect that is somewhat larger than the one we report in Column IV of Table 2 (1.75), but fairly close to the one we report in Column III (2.77). They also use a different proxy for the return on assets based on EBITDA (earnings before interest, tax, depreciation, and amortization) in their regressions. For comparison, we re-estimated our two benchmark 
models using EBITDA instead of net income as the numerator for $R O A$. Our estimates for the coefficient on founderCEO are $0.031(t=2.35 ; p$-value $=0.01)$ and $0.026(t=1.85$; $p$-value $=0.064)$ for the first and second model, respectively, which are quite similar to the estimate of 0.035 in Anderson and Reeb (2003). ${ }^{13}$

Overall it appears that the magnitude of the estimated coefficient on the founder-CEO dummy in a linear performance regression is not very sensitive to the choice of the set of control variables. Furthermore, survivorship biases do not appear to be a major concern in such regressions. Anderson and Reeb's (2003) procedure of choosing firms in the S\&P 500 in 1992 and then following them until 1999 introduces a very different type of selection bias than our approach of choosing the firms in the Fortune 500 in 1998 and following them back in time. Nevertheless, the fact that our estimates are virtually identical to theirs is a signal that these different types of survivorship biases are not creating a discrepancy between the two sets of findings. Thus the positive relationship between the retention of the CEO title by one of the founders and both market and accounting measures of firm performance appears to be fairly robust. The important question, to which we turn next, is how should one interpret this relationship? Should one conclude that the retention of the CEO title by one of the company's founders leads to superior performance? Or is it the other way around, that is, is superior performance a reason for a founder to remain as CEO? Or is it both? To gain further insight into the nature of the relationship between founder-CEOs and firm performance, we will try to disentangle these different effects in the remainder of the paper.

\section{Assessing the Causal Relationships between Founder-CEOs and Firm Performance}

\subsection{Two-Stage Least Squares Estimates}

In this section we use two-stage least squares methods to try to isolate the effects of founderCEOs on performance from other sources of variation. We first discuss the validity of the two different variables that we use as instruments for founderCEO, which are dead founders and the number of founders, and then we describe the results of our 2SLS regressions. Details on the construction of the instruments and their summary statistics are provided in

\footnotetext{
${ }^{13}$ Although our results are similar when we use EBITDA instead of net income to construct $R O A$, it is easier to detect evidence consistent with the existence of an endogeneity problem using EBITDA. Thus we choose to use net income instead of EBITDA to be more conservative.
} 
the Appendix.

\section{- Dead Founders}

The first variable we use as an instrument is a dummy variable that takes the value of 1 if the founder died before the start of our sample period and zero otherwise (if there are multiple founders, we take the average of this variable among all founders). The motivation for this instrument is simple: dead founders cannot be CEOs. However, to be a good instrument dead founders must also be uncorrelated with performance except through explanatory variables contained in the second stage regression. We find it unlikely that founders' deaths are caused by performance. The death of a founder should be a fairly exogenous event which will affect the likelihood that the current CEO is one of the founders but that does not have a plausible direct effect on performance, except when the founder happens to be the CEO.

\section{- Number of Founders}

The second variable we use as an instrument is the number of founders of each firm. We believe that this variable also satisfies the conditions necessary for a valid instrument. First, the probability that the current CEO is one of the founders is mechanically increasing in the number of founders, although since one founder often plays a more dominant role than the others we expect this correlation to be weaker than in the case of our other instrument. ${ }^{14}$ Second, it should be fairly exogenous in our setup. In particular, the number of founders is unlikely to have any direct effect on firm performance years after the founding event.

Table 3 reports the outcomes of the first-stage regressions of founderCEO on our two instruments and the other controls from the models (1) and (2). From Table 3 we see that both proposed instruments are strongly correlated with founderCEO: consistent with intuition dead founders enters the regressions negatively with $t$-statistics of -17.16 and

\footnotetext{
${ }^{14}$ The case of Arrow Electronics illustrates how the number of founders may influence whether or not the current CEO is a founder (see Hoovers 2002, Fortune, January 12, 1981, p. 19 and The New York Times, December 6, 1980, p. 26). In 1968 three friends led a group of investors in acquiring a then obscure company called Arrow Electronics Corporation. After merging it with another company, they used it to found what is now one of the largest distributors of electronic components in the country. One of the partners, Duke Glenn, Jr., was the Chairman and CEO. The other two were Executive Vice-Presidents. In 1980 a hotel fire killed 13 members of Arrow's senior management including the founder/CEO and another founder. The remaining founder, John Waddell, was immediately named acting CEO and remained CEO with only brief interruptions until 1986. Although Waddell's primary responsibilities were in corporate administration and communications before the fire, the crisis led the board to choose him as acting CEO because he was one of the original founders.
} 
-11.94 in columns I and II, respectively, while the number of founders enters them positively with $t$-statistics of 4.10 and 4.66 in columns I and II, respectively.

In Table 4, we report the results of the second-stage regression using model (1) for the two performance measures. From Columns I and II we see that founderCEO is significantly positively related to $\log Q$ at the $1 \%$ significance level (the $p$-values are always lower than 0.001). Similarly, in Columns III and IV we see that founderCEO is significantly positively correlated with $R O A$ at the $1 \%$ significance level (the $p$-values are always lower than 0.004 ). These results suggest a causal positive effect of founder-CEOs on performance. Under the assumption that our instruments are valid, our results suggest that firms with founders as their CEOs appear to perform better than others on average.

Perhaps surprisingly, the 2SLS results are not consistent with the idea that good performance is a reason for a founder to remain as CEO, since all estimated coefficients on founderCEO are larger when we use 2SLS instead of OLS. Furthermore, the differences between the 2SLS and the OLS results are statistically significant. At the bottom of Table 4, we report the differences between the 2SLS and OLS estimates of the effect of founderCEOs on performance, along with their $t$-statistics, which are computed using the method in Hausman's (1978) specification tests. We find that all differences are statistically different from zero at the $1 \%$ significance level. Thus, under the maintained assumption that the instruments are valid, this finding is consistent with the idea that good performance might actually reduce the likelihood that a founder retains the CEO title, which explains why the OLS effects are smaller than the 2SLS effects.

Under the maintained assumption that our instruments are valid, we cannot reject that there is significant endogeneity in the one-equation procedures that try to estimate the effect of founder-CEOs on market and accounting measures of performance. Thus, OLS procedures that ignore the endogeneity of founder-CEO status in performance regressions, such as the ones in the previous section, can be potentially misleading because they generate inconsistent estimates of the economically relevant parameter of interest. In addition, the larger values of our 2SLS estimates suggest that once one factors out the direct effect of founder-CEOs on performance that is induced by our instruments, the remaining correlation between firm performance and the likelihood that a founder retains the CEO title is negative. This result is not consistent with the intuition advanced in several recent studies examining the effect of founder-CEOs on performance (Anderson and Reeb, 2003; Fahlenbrach, 2005), that good performance should lead founder-CEOs to retain their titles. 
If we take the estimated coefficient on founderCEO from the 2SLS regression of model (2) as our estimate of the effect of founder-CEOs on $Q$, our results imply that a firm with average $Q$ will experience a drop of 3 units in its $Q$ if its CEO is not also one of its founders. This effect is almost 10 times larger than the one estimated by OLS. While a negative causal relationship from performance to founder-CEOs would imply that the OLS estimates of the effect of founder-CEOs on performance are biased downward, it seems unlikely that the true effect should be so large. In the next section, we therefore investigate whether the extent of the difference between the OLS and 2SLS results is a result of model misspecification.

\subsection{Endogenous Dummy Variable Model}

A puzzling result from the previous subsection is the size of the estimated marginal effect of founder-CEOs on performance. It is thus natural to ask whether these values are robust to different econometric procedures: Is there something specific to the 2SLS procedure we are using that is producing excessively large estimates? Or is the effect of founder-CEOs on performance really that big?

One noticeable feature of our 2SLS procedure is that, although founderCEO is binary, in the first-stage regression we ignore the discrete nature of this variable. Two-stage least squares consistency of the second stage does not hinge on getting the functional form right in the first stage, so one does not necessarily have to use a discrete dependent variable model for a dummy endogenous variable (see Angrist and Krueger, 2001). However, 2SLS leads to biased estimates in finite samples and it is not known how misspecification in the first stage may affect this bias. Therefore, in this section we jointly estimate a system of equations in which we explicitly account for the binary nature of founderCEO.

We formulate the following model:

$$
\begin{aligned}
& y=b_{0}+b_{1} \text { founderCEO+X } \mathbf{\beta}+u_{1} \\
& I=\mathbf{Z} \boldsymbol{\alpha}+u_{2} \\
& \text { founderCEO }=\left\{\begin{array}{l}
1 \text { if } I \geq I^{*} \\
0 \text { if } I<I^{*}
\end{array}\right.
\end{aligned}
$$

where $u_{1} \backsim N\left(0, \sigma^{2}\right), u_{2} \backsim N(0,1)$ and $\operatorname{corr}\left(u_{1}, u_{2}\right)=\rho$. Equation (3) is the same one we have estimated by single-equation procedures: the vector of controls $\mathbf{X}$ varies depending on whether we are estimating model (1) or (2). Equation (4) models the determinants of founders retaining the CEO title. $I$ is an unobservable variable that measures the aggregation of forces that favor retaining a founder as the CEO. The determinants of $I$ are the 
observable variables $\mathbf{Z}$ that one believes should affect the likelihood that a founder keeps the CEO title plus an unobserved error $u_{2}$. Equation (5) is the function that models the decision to keep a founder as the CEO: founders retain the CEO title if and only if $I$ is above an (unobservable to the econometrician) threshold level $I^{*}$.

The model above is one example of an endogenous dummy variable model (Heckman, 1978). Notice that the correlation between the errors of the two equations allows many interpretations. For example, if unusually good performance implies that the founder is more likely to retain the CEO title, we should expect $\rho$ to be positive. We should also expect $\rho$ to be positive if there is an omitted variable that affects performance and founderCEO in the same direction. However, the results from the previous section suggest that, once one factors out the direct effect of founder-CEOs on performance, the remaining correlation between firm performance and the likelihood that a founder retains the CEO title is negative. This suggests that $\rho$ is negative.

We can estimate the above system of equations by maximum likelihood to get estimates of all relevant parameters. ${ }^{15}$ We use dead founders and number of founders as our main determinants of $I$ in the second equation. The first equation replicates the models (1) or $(2)$.

Table 5 reports the results for both models and both performance measures. As before, the direct effect of founderCEO on performance is always positive and significant at all conventional significance levels. It is also true that all estimated coefficients are larger than their OLS counterparts, which is consistent with the results from the previous subsection. However, the magnitudes of these effects are no longer so large: for example, the estimates from column II suggest that a firm with average $Q$ will experience a drop of 0.78 units in its $Q$ when its CEO is not one of its founders. This effect is about twice as large as the one estimated by OLS but much lower than our 2SLS estimate. We conclude that the magnitudes of our 2SLS estimates are not robust to changes in model specification. However, the evidence that there is a direct positive effect of founder-CEOs on performance remains overwhelming.

At the bottom of Table 5 we report our estimates of the correlation between the errors of the two equations, $\rho$. Consistent with the hypothesis that good performance might reduce the likelihood that a founder retains the CEO title, we find that $\rho$ is always negative in

\footnotetext{
${ }^{15}$ This model is identical to the standard average treatment effects model encountered in the program evaluation literature (see Maddala, 1983, for many examples).
} 
all four columns. The estimated correlation between the errors of the two equations also appears quite sizeable: it is approximately -0.4 in the $Q$ models. Wald tests of the null that this correlation is zero yield $p$-values lower than $5 \%$ in all four cases, and lower than $1 \%$ in three of the four cases. Since testing the null that the correlation coefficient $\rho$ is zero is an explicit test of the exogeneity of founder-CEO status (under the assumption that the model is otherwise correctly specified), we reject the null that the two equations in (3) and (4) are independent in all of our specifications. ${ }^{16}$

We summarize the results in this section as follows. We confirm the previous findings that firms that keep one of their founders as their CEOs perform better than the ones that do not, but the extremely large estimated partial effects of founder-CEOs on performance that we found in the previous subsection appear to be a feature of our 2SLS specification. Most importantly, we again find strong evidence that founder-CEO status is not independent of performance, and that once one factors out the direct effect of founder-CEOs on performance, the remaining correlation between firm performance and the likelihood that a founder retains the CEO title is negative. This is consistent with different interpretations and we discuss the reasonableness of some of these interpretations in more detail in the next section.

\section{Better Performance Leads to Fewer Founder-CEOs: Addi- tional Evidence and Possible Explanations}

The finding that firms with relatively good performances are less likely to be run by founderCEOs is somewhat surprising, both because the idea that good performance might make founder-CEOs less likely to relinquish their titles has some intuitive appeal and because of our evidence of a causal positive effect of founder-CEOs on performance. Thus, the purpose of this section is to uncover some additional empirical relationships that might help us better understand this finding. We first advance some possible explanations for this result and then we discuss which ones are consistent with our data.

\section{Bad Governance}

There is a large amount of evidence showing that poor performance increases the likelihood of CEO turnover (e.g., Warner, Watts and Wruck, 1988; Weisbach, 1988; see also Goldman, Hazarika and Shivdasani, 2003, for a comprehensive list of papers documenting

\footnotetext{
${ }^{16}$ If we construct our proxy for $R O A$ using EBITDA instead of net income, we always reject the null of independence of equations at the $1 \%$ significance level.
} 
this relationship). However, in firms with entrenched CEOs this link between poor performance and turnover should be weak. Morck, Shleifer and Vishny (1989) provide some evidence of entrenchment of founder-executives. In a sample of Fortune 500 firms, they find that firms whose top management teams contain members of the founding-family are less likely to experience a complete turnover of top executives and are less likely to be targets of hostile takeovers than other firms. However, this type of entrenchment is not sufficient to explain our findings, because it only suggests that poor performance might have a small positive or no effect on the likelihood of a founder-CEO being replaced. In fact, we need a stronger notion of bad governance to explain our findings: poor performance should decrease the likelihood of founder-CEO turnover. This could happen if bad governance also has a direct negative effect on performance. In this case, the negative correlation between the errors of equations (3) and (4) could be due to an omitted variable measuring the overall quality of governance: firms with bad governance are more likely to perform badly and to have a founder who is entrenched. Thus, the bad governance hypothesis suggests that poor performance and the likelihood of replacing a founder-CEO should be negatively related. According to this hypothesis, however, there is no reason for the CEO to leave the firm after good performance.

\section{Controlled Succession}

Suppose that, after good performance, CEOs are more likely to be able to choose their successors (Morck, Shleifer and Vishny, 1989). In fact, Morck, Shleifer and Vishny (1989) claim that ordinary CEO successions are more likely to occur after periods of abnormally good performance. Founders in particular may value the ability to control succession, for it allows them to transfer control to their heirs. Thus, the controlled succession hypothesis predicts that founder-CEOs will step out after some period of consistently good performance, while it has no prediction for how founder-CEO turnover is affected by bad performance.

\section{Founder Benevolence and the Paradox of Entrepreneurial Success}

Suppose that founders believe they have superior managerial capabilities (whether this is actually true is not important for the argument). Suppose also that founders are benevolent, i.e. they care more about the future of the company than a $\mathrm{CEO}$ who is not one of the original founders. Founders may therefore want to leave their companies only when they are in good shape. For example, Wasserman (2003) argues that a founder-CEO's success in achieving critical milestones, such as a successful completion of product development, makes it more likely that he will step down. He calls this phenomenon "the paradox of 
entrepreneurial success."

\section{Wealth Effects}

Founder-CEOs who have much of their wealth invested in the firm benefit greatly from good firm performance. If they want to retire when rich, they should be more willing to retire early following good performance. Thus there should be a positive relationship between past good performance and the likelihood of subsequent founder-CEO departures. A related but somewhat darker story is that founder-CEOs might be better informed than other shareholders and may choose to leave the firm and sell their shares when performance is unusually high. Thus, founder-CEOs may leave their firms to "cash in" before the market valuation of their shares deteriorates. In both cases "wealth effects" are important, i.e. founder-CEOs want to leave their firms exactly when their firm-related wealth is high.

In order to explore the empirical relevance of these hypotheses, ${ }^{17}$ we assess how well past performances, both good and bad, help predict future changes in command in which a founder-CEO steps out. Thus we use the timing of events as an identification strategy. There are two main limitations of this procedure. First, predictive power does not imply causation, especially when variables reflect the behavior of forward-looking agents. Thus, we expect market measures of performance to be more plagued by endogeneity problems in predictive regressions than accounting measures, because the latter tend to be less influenced by the expectation of future events. Second, and perhaps most importantly, our tests in the previous sections detected a negative contemporaneous effect of performance on founderCEO status. To the extent that performance exhibits some persistence, our approach in this section should be able to shed some light on the causes of this effect. However, one cannot fully capture this effect without accounting for its strictly contemporaneous component, for which identification by means of timing is not feasible.

Our empirical strategy is as follows. When a CEO who is not a founder is replaced, this typically (though not necessarily) implies that the new CEO is also a non-founder.

\footnotetext{
${ }^{17}$ An additional hypothesis that could be consistent with our finding is what might be called a "CEO Manipulation of Earnings and Short-Horizon" problem. When CEOs are approaching the date when they expect to depart from a firm, a horizon problem arises. Because they will not be around to collect the benefits of long-term investments, they might have an incentive to cut expenses prior to expected departures in order to boost earnings, which might be positively linked to CEO pay. This effect would cause accounting measures of performance to be artificially high right before CEO turnover. We do not explicitly analyze this hypothesis here, because previous evidence on this topic leads us to believe that it is unlikely that this effect is driving our results. For example, Murphy and Zimmerman (1993) find little evidence supporting the short-horizon problem. In fact, they find that while there might be some evidence that managers take actions that increase accounting earnings prior to CEO departures, these cases are restricted to poorly performing firms, implying that this effect is more likely to be associated with poor governance in general.
} 
Therefore, turnover data in firms which are not initially run by founders are not useful for our purposes. Accordingly, we restrict our sample to firms that were run by one of their founders in any year in our sample. We then generate an indicator variable called stepout that takes the value of 1 in the firm-years in which a founder-CEO steps out and 0 otherwise. For each firm that has experienced a change of command in this restricted sample, we leave out all observations in the years after the one in which the founder has relinquished the CEO title. This sample selection procedure severely reduces the number of usable observations. We therefore expanded our sample to increase the number of changes in command for founder-CEOs. To do this we used Forbes executive compensation surveys (Forbes, 19921999), which identify whether or not the CEOs of the Forbes 800 are founders. We first matched ExecuComp to the Forbes 800 firms to identify further instances of firms whose founders were CEOs. We then tracked these additional firms in the Forbes compensation surveys until 2001 to identify when the founder no longer held the CEO title. By this procedure we were able to expand our sample of founder-CEO departures from 23 to 50 . We also identified 535 firm-years in which stepout is equal to zero. We obtain performance measures and other controls, such as total assets, volatility, CEO ownership, and CEO tenure, from ExecuComp for the additional firm-years.

The theories we have outlined have predictions for how founder-CEO departures should be differentially affected by either good or bad past performance. Thus, in principle the relationship between performance and the likelihood of founder-CEO departures is potentially non-monotonic. In order to jointly test some of these hypotheses, we have to impose some empirical specifications that allow for the possibility of a non-monotonic relationship between the dependent and independent variables.

A simple and intuitive procedure that is well suited for our purposes is as follows. We create a dummy variable called high $Q$ that equals 1 for very high values of lagged $Q$ and is zero otherwise. We consider $Q$ to be high if it is in the top quartile of the full sample $Q$ distribution for that given year. Similarly, we create a dummy variable called low $Q$ that equals 1 whenever $Q$ is in the bottom quartile of the full sample $Q$ distribution for that given year, and is zero otherwise. The variables highROA and lowROA are defined in an analogous way. Because we want to see the effects of persistent past performance on CEO turnover, we use the averages of one- and two-year lagged $Q$ and $R O A$ to construct our measures of extreme performance. ${ }^{18}$ Theses variables partially capture the relative nature

\footnotetext{
${ }^{18}$ We chose two years because using three or more years would severely restrict our sample size.
} 
of performance, that is, how the firm is performing in relation to others. ${ }^{19}$

Table 6 presents the results of Probits estimating the likelihood of a founder-CEO stepping out as a function of $\operatorname{high} Q$ and $\operatorname{low} Q$ and year dummies, and also as a function of highROA and lowROA and year dummies. As one can see from column I, we find that the estimated coefficients on $\operatorname{high} Q$ and $\operatorname{low} Q$ are both positive but not significant. From column II, however, we find that both highROA and lowROA help predict future changes in which a founder-CEO steps out.

The lack of predictive power of $Q$ is not surprising. It is a well established fact in the CEO turnover literature that accounting measures of performance are better predictors of turnover than market measures (Weisbach, 1988; Murphy and Zimmerman, 1993). In fact, Hermalin and Weisbach (1998) claim that this is exactly what theory predicts: accounting measures of performance reflect the characteristics of current managers, while stock market based measures of performance should also reflect the expectation of future management changes.

The finding that past poor performance as measured by $R O A$ increases the likelihood that a founder-CEO will leave the firm is at odds with the bad governance hypothesis. This result is not surprising, given the well-documented evidence on the disciplining role of CEO dismissals (Warner, Watts and Wruck, 1988; Weisbach, 1988). What our evidence adds to this literature is the confirmation that founders are not immune to this disciplining device.

On the other hand, the finding that past good performance as measured by ROA increases the likelihood that a founder-CEO will leave the firm in the near future is consistent with the other three hypotheses: controlled succession, founder benevolence and wealth effects.

Before we try to further discriminate among these hypotheses, we briefly consider some robustness checks. First, our choice of cutoff (25\%) to define both high and low performance is not important. Choosing any cutoff in the range of $10 \%$ to $35 \%$ always leads to estimated parameters that are significant at least at the $10 \%$ level in the $R O A$ specification. As expected, as the cutoff approaches $50 \%$ the effects become much weaker and eventually not significant. For cutoffs lower than 10\%, the standard errors tend to go up, which is consistent with the intuition that the precision of our estimates should decrease as the

\footnotetext{
${ }^{19}$ Changing the comparison group appears to have only minimal effects on these variables. For example, in earlier versions of this paper we have used the full sample (1992-1999) as the comparison group, and the results were almost exactly identical.
} 
number of firms that are considered to be performing extremely well or extremely badly decreases.

We also experimented with including other controls in our specifications (not reported in the tables). Firm-level controls do not have significant effects on the probability of a founder-CEO departure. For example, firm size (proxied by the log of total assets) and volatility have no significant effect on founder-CEO departures. Their inclusion also does not change the significance of the results reported in Table 6 . On the other hand, CEO tenure and $\mathrm{CEO}$ age do have significant effects on founder-CEO departures, but again they have minimal impact on the estimated effects of both bad and good performance on CEO departures.

As a final robustness check, we also tried a more flexible specification that is capable of capturing richer non-monotonic relationships between performance and the probability of CEO departures. For each performance measure, we created two new variables: we interact both the high and the low performance dummies with the average of one- and two-year lagged performance. We estimate Probits using both the dummies and the interaction terms. This specification allows us to capture the additional effect that, for example, performance has on founder-CEO departures conditional on performance being high. It also allow us to better explore the continuous nature of the underlying performance variables. We report the results of these extended specifications in columns III and IV of Table 6 . We see that the significance of the effects of both the low and high performance dummies is not affected by the inclusion of the interaction terms. Furthermore, these interaction terms appear to have no additional predictive power. This suggests that our original simpler specification is capturing most of the effects of performance on the likelihood of founderCEO departures, consistent with previous evidence that the performance-CEO turnover relationship is characterized by threshold effects (e.g. Goldman, Hazarika and Shivdasani, 2003).

To further discriminate among our hypotheses, we examine the importance of wealth effects in Table $7 .{ }^{20}$ If wealth effects are important determinants of founder-CEO departures, one should expect that founder-CEOs with more firm-related wealth leave more often. In column I, we see that the opposite holds: founder-CEOs with higher ownership stakes are less likely to leave the firm. Of course, ownership may affect the likelihood of departure

\footnotetext{
${ }^{20}$ We only report results using $R O A$. As before, the regressions using $Q$ suggest similar results, but they are never significant.
} 
for reasons that are not related to CEO wealth. For example, CEOs with more ownership might be more entrenched and thus less likely to be forced to leave. Strictly speaking, wealth effects should play a role only when CEOs are departing after good performance. To test this hypothesis more directly, we create a dummy variable that takes the value of 1 if founder-CEO ownership is "high" and 0 otherwise. We define high ownership as an aboveaverage equity stake (the average ownership of founder-CEOs in our sample is approximately $5 \%$ ). We then interact the high ownership dummy with both highROA and lowROA. If founder-CEOs are departing after periods of good performance due to wealth effects, then we should expect that the sensitivity of departure to good performance should be higher when they have more ownership. Thus, we expect the interaction between highROA and highOWNERSHIP to have a positive effect on the probability of CEO departure. From

column II, we see that this interaction term actually enters with a negative sign and is not significantly different from zero. Overall, we find no support for the hypothesis that wealth effects are responsible for the positive correlation between high performance and founder-CEO departures in our sample.

Our conclusions are as follows. The finding that firms with relatively good performances are less likely to be run by founder-CEOs appear to be due more to founders choosing to relinquish control after periods of good performance than to an omitted variable correlated with bad governance. In addition, our evidence suggests that wealth-effects are not driving our results. This implies that the hypotheses most consistent with our evidence are the controlled-succession and the founder-benevolence hypotheses.

\section{Conclusions}

In this paper, we provide strong evidence that founder-CEO status is influenced by firm performance. Using methods based on instrumental variables, we find that firm performance has a negative effect on the likelihood that a firm is run by one of its founders. This result is not sensitive to model specification, to alternative measures of performance, or to econometric procedures. After factoring out the negative effect of performance on founder-CEO status, we obtain a positive causal effect of founder-CEOs on firm performance, an effect that is quantitatively larger than the effect estimated through standard OLS regressions.

In order to further understand this negative effect of performance on founder-CEO status, we estimate the probability of founder-CEO departures as a (potentially non-monotonic) 
function of past performance. Our main finding is that past superior accounting performance increases the likelihood that founder-CEOs will step out. Our evidence is not consistent with the hypothesis that an omitted variable correlated with bad governance can explain the negative relationship between firm performance and founder-CEO status nor with the hypothesis that founder-CEOs leave once they are wealthy enough. This leaves us with two potential arguments that might explain our new finding: (1) founder-CEOs may value control over their succession more than non-founders, and (2) founder-CEOs may want to leave their companies "in good shape."

Our paper has implications for the growing literature on family firms. The positive effect of founders on performance suggests that the higher performance of family firms (Anderson and Reeb, 2003) could be driven primarily by firms where the current CEO is a founder. Thus, there might be significant distinctions between founder control and family control. In addition, the finding that firms with relatively good performances are less likely to be run by founder-CEOs may help explain the negative correlation between inherited control and performance (e.g. Pérez-González, 2002). If performance is mean reverting and founders leave at its peak, one should observe a decline in performance when founders transfer control to their heirs even when inherited control is not bad for performance. This interpretation is most likely to be true if founders value the ability to transfer control to their heirs, because in this case high performance might make it easier for founders to control succession. Our results suggest that studying the differences between founder-CEO succession and the succession of professional CEOs should provide interesting topics for future research.

\section{Appendix - Construction of Instruments}

In this section, we discuss the construction of the instruments for the dummy variable founderCEO indicating whether or not the CEO is also one of the company's founders. As we discussed in section 5 , we use two instruments for this dummy. The first is the proportion of a company's founders who are dead prior to the time our data starts (1992). The second is the number of founders of the company.

We collected the data necessary to construct the instruments from a variety of sources using Lexis-Nexis as well as the International Directory of Company Histories (various volumes) and company histories on company websites when available. In order to determine 
who the founders of the firms in our sample are, we first had to establish what the founding event of the firm in its form in which it appears in 1998 was (since our firms are taken from the 1998 Fortune 500 list). We consider the following four types of events to be founding events: a simple business start-up (e.g. a shop opening), a merger of equals, a spin-off of a division that was not previously a separate company that had been acquired and a major change in ownership, e.g. an LBO, MBO or other acquisition, that leads to a major change in the development of the company. In the case of a merger of equals, we consider the founders of the new company to be the founders of both firms that are merging. In the case of a spin-off we consider the founders to be the founders of the original company, as well as the CEO at the time of the spin-off if he appears important to the development of the company. If a company was acquired and spun-off again, we consider the founders to be the founders of the company pre spin-off. We also generally consider any person to be a founder of the company who is identified as such in any of our data sources. In some cases our sources also identify important investors in the company or the first CEO who was hired by a founder as founders.

Our procedure was to use the company descriptions in the International Directory of Company Histories and the histories of the companies in Hoover's Company Profile Database, as well as information on the founders of the 1992 Fortune 200 firms in the National Commission on Entrepreneurship's (2001) study on entrepreneurs as a starting point for identifying the founding event, and if possible, the names of the founders. This procedure worked better for firms that were founded recently than for older firms that had undergone several mergers or restructurings. Generally older firms tended to have company histories on their websites that we could use to identify what the firm considers to be its main founding event. Once we identified the founding events, we searched archived stories from the sources Forbes, Fortune and U.S. News on Lexis-Nexis for further information on the founders of the company and information on whether or not the founders died prior to 1992 and the year the founders died. We consider a founder to be alive after 1992 when we could either verify that he was alive after 1992 or we could not find an obituary for the founder and the founder is mentioned in news articles as playing an important role in the company after 1975. If we are unable to find the name of a founder, we consider him to be alive if most of the other founders are alive. Otherwise, we consider a founder to be dead. When we were unable to find the necessary information on Lexis-Nexis, we searched for the founders using Forbes' Peopletracker and the internet. 
Our final data set consists of 580 observations on founders for 321 firms in our sample. Our instruments are a straightforward per-firm average of the dummy indicating whether the founder died prior to 1992 and the per-firm sum of all founders.

To reduce data collection costs, we did not collect data on founders for a random sample of 63 firms that had been incorporated more than 64 years prior to 1992 out of these 321 firms. For these firms we assume that there was only one founder and that the founder died prior to 1992. Since it is highly likely that the founders of these firms all died prior to 1992 and the probability that any of the founders are the CEO in 1994 is very low, we do not expect this shortcut to affect our results. Similarly, when the parties involved in a merger of equals themselves were the product of mergers of equals, we consider the firm to have two founders who died prior to 1992. Since these firms were all older firms and the influence of the original founders of each component firm is likely to be very small after several restructurings, this coding is consistent with the fact that it is highly unlikely that any of the founders is the CEO in 1994.

Of the 258 firms for which we collected detailed founder data, most were founded by simple business start-ups. Approximately 21 firms were founded through mergers of equals and 13 were founded as the result of a spin-off. The average number of founders in our sample is 1.8 with a standard deviation of 1.1 and a maximum of 8 founders. $50 \%$ of the firms were founded prior to 1961. This is reflected in the fact that the average proportion of founders who died prior to 1992 is $70.3 \%$ with a standard deviation of $43.5 \%$. 


\section{References}

[1] Anderson, R., and D. Reeb, 2003, "Founding-Family Ownership and Firm Performance: Evidence from the S\&P 500," Journal of Finance, 58, 1301-1328.

[2] Anderson, R., S. Mansi, and D. Reeb, 2003, "Founding-Family Ownership and the Agency Cost of Debt," Journal of Financial Economics, 68, 263-285.

[3] Angrist, J., and A. Krueger, 2001, "Instrumental Variables and the Search for Identification: From Supply and Demand to Natural Experiments," Journal of Economic Perspectives, 15, 69-87.

[4] Burkart, M., F. Panunzi, and A. Shleifer, 2003, "Family Firms," Journal of Finance, $58,2167-2201$.

[5] Fahlenbrach, R., 2005, "Founder-CEOs and Stock Market Performance," working paper, Wharton School.

[6] Goldman, E., S. Hazarika, and A. Shivdasani, 2003, "What Determines CEO Turnover?", working paper, University of North Carolina-Chapel Hill.

[7] Hausman, J. A., 1978, "Specification Tests in Econometrics," Econometrica, 46, 12511271.

[8] Heckman, J. J., 1978, "Dummy Endogenous Variables in a Simultaneous Equations System," Econometrica, 46, 931-960.

[9] Hermalin, B. E., and M. S. Weisbach, 1998, "Endogenously Chosen Boards or Directors and Their Monitoring of the CEO," American Economic Review, 88, 96-118.

[10] Himmelberg, C., G. Hubbard, and D. Palia, 1999, "Understanding the Determinants of Managerial Ownership and the Link between Ownership and Performance," Journal of Financial Economics, 53, 353-84.

[11] International Directory of Company Histories, 1988-2001, St. James Press, Chicago.

[12] Jayaraman, N., A. Khorana, E. Nelling, and J. Covin, 2000, "CEO-Founder Status and Firm Financial Performance," Strategic Management Journal, 21, 1215-1224.

[13] Jensen, M., and K. J. Murphy, 1990, "Performance Pay and Top Management Incentives," Journal of Political Economy, 98, 225-264. 
[14] Johnson, B., R. Magee, N. Nagarajan, and H. Newman, 1985, "An Analysis of the Stock Price Reaction to Sudden Executive Deaths," Journal of Accounting and Economics, $7,151-174$.

[15] Maddala, G. S., 1983, Limited-Dependent and Qualitative Variables in Econometrics. Econometric Society Monographs, Cambridge University Press.

[16] McConaughy, D., M. Walker, G. Henderson, and C. Mishra, 1998, "Founding Family Controlled Firms: Efficiency and Value," Review of Financial Economics, 7, 1-19.

[17] Morck, R., A. Shleifer, and R. Vishny, 1988, "Management Ownership and Market Valuation: An Empirical Analysis," Journal of Financial Economics, 20, 293-315.

[18] Morck, R., A. Shleifer, and R. Vishny, 1989, "Alternative Mechanisms for Corporate Control," American Economic Review, 79, 842-852.

[19] Morck, R., D. Strangeland, and B. Yeung, 1998, "Inherited Wealth, Corporate Control and Economic Growth: a Canadian Disease?," NBER Working paper, no. 6814.

[20] Murphy, K. J., and J. L. Zimmerman, 1993, "Financial Performance Surrounding CEO Turnover," Journal of Accounting and Economics, 16, 273-315.

[21] National Commission on Entrepreneurship, 2001, "From the Garage to the Boardroom: The Entrepreneurial Roots of America's Largest Corporations," report.

[22] Palia, D., and A. Ravid, 2002, "The Role of Founders in Large Companies: Entrenchment or Valuable Human Capital," working paper, Rutgers University.

[23] Pérez-González, F., 2002, "Inherited Control and Firm Performance," working paper, Columbia Business School.

[24] Schwert, B., 1985, "A Discussion of CEO Deaths and the Reaction of Stock Prices," Journal of Accounting and Economics, 7, 175-178.

[25] Shleifer, A., and R. Vishny, 1989, "Managerial Entrenchment: The Case of ManagerSpecific Investments," Journal of Financial Economics, 25, 123-139.

[26] Slovin, M., and M. Sushka, 1993, "Ownership Concentration, Corporate Control Activity, and Firm Value: Evidence From the Death of Large Blockholders," Journal of Finance, 48, 1293-1321. 
[27] Stein, J. 1989, "Efficient Capital Markets, Inefficient Firms: A Model of Myopic Corporate Behavior," Quarterly Journal of Economics, 104, 655-669.

[28] Villalonga, B. and R. Amit, 2005, How Do Family Ownership, Management, and Control Affect Firm Value?, forthcoming, Journal of Financial Economics.

[29] Warner, Jerold B., Watts, Ross L., and Karen H. Wruck, 1988, "Stock Prices and Top Management Changes," Journal of Financial Economics, 20, 461-492.

[30] Wasserman, N., 2003, "Founder-CEO Succession and the Paradox of Entrepreneurial Success," Organization Science, 14, 149-172.

[31] Weisbach, M. S., 1988, "Outside Directors and CEO Turnover," Journal of Financial Economics, 20, 431-460.

[32] Zhou, X., 2001, "Understanding the Determination of Managerial Ownership and its Relationship to Firm Performance," Journal of Financial Economics, 62, 559-71.

[33] Zingales, L., 1995, "What Determines the Value of Corporate Votes," Quarterly Journal of Economics, 110, 1047-1073. 


\section{Table 1: Summary Statistics}

Sample consists of 321 publicly traded, non-regulated firms from the 1998 Fortune 500 that were available on ExecuComp (2000) during the years 1992-1999. Most financial and CEO data are from ExecuComp (2000). Firm age is collected from Moody's Manuals (1999), proxy statements and 10-Ks for fiscal 1998. Founder data are from a variety of sources consisting of proxy statements, annual reports and the internet. Our proxy for Tobin's $Q$ is $=$ (book value of assets-book value of equity + market value of equity)/book value of assets. $R O A=$ net income before extraordinary items and discontinued operations/book value of assets. FounderCEO is equal to one if the CEO is a founder of the company. CEO ownership is defined as the ratio of the number of shares owned by the CEO after adjusting for stock splits to total shares outstanding. CEO tenure is the number of years since the CEO was appointed CEO. CEO equity-based pay is the value of annual option pay divided by the sum of salary, bonus and annual option pay. Volatility is the Black-Scholes volatility as reported in ExecuComp. Firm age is the number of years since the firm's first date of incorporation.

\begin{tabular}{lccccc}
\hline \hline Variable & & & & & \\
& Mean & St. Dev. & Min. & Max. & No. Obs. \\
\hline$Q$ & 2.05 & 1.40 & 0.83 & 19.16 & 2128 \\
$\log Q$ & 0.59 & 0.46 & -0.18 & 2.95 & 2128 \\
$R O A$ & 5.68 & 5.75 & -48.19 & 48.15 & 2128 \\
FounderCEO & 0.11 & 0.31 & 0.00 & 1.00 & 2128 \\
CEO ownership & 0.02 & 0.05 & 0.00 & 0.44 & 2128 \\
CEO tenure & 7.36 & 7.24 & 0.00 & 47.00 & 2128 \\
CEO equity-based pay & 0.47 & 0.29 & 0.00 & 1.00 & 2128 \\
Volatility & 0.29 & 0.11 & 0.12 & 1.05 & 2128 \\
Firm assets (log) & 8.72 & 1.07 & 5.78 & 12.91 & 2128 \\
Firm age (log) & 3.82 & 0.89 & 0.00 & 4.98 & 2128 \\
\hline \hline
\end{tabular}




\section{Table 2: OLS Regressions of Firm Performance on Founder-CEO Status}

This table reports results of regressing firm performance (measured alternatively by $\log Q$ and $R O A$ ) on founder-CEO status. Columns I and II report results using $\log Q$ as the performance measure. Columns III and IV report results using ROA. For each performance measure, we estimate the empirical model in equations (1) and (2) in the text using OLS. All data is described in Table 1. The estimation period is 1992-1999. All regressions include year effects and 2-digit SIC industry dummies. The estimations correct the error structure for heteroskedasdicity and within-firm correlation using the Huber-White estimator. $t$-stats (in parentheses).

\begin{tabular}{|c|c|c|c|c|}
\hline \multirow[b]{3}{*}{ Indep. Variables } & \multicolumn{4}{|c|}{ Dependent Variable } \\
\hline & \multicolumn{2}{|c|}{$\log Q$} & \multicolumn{2}{|c|}{$R O A$} \\
\hline & (I) & (II) & (III) & (IV) \\
\hline FounderCEO & $\begin{array}{l}0.242^{* * *} \\
(3.31)\end{array}$ & $\begin{array}{l}0.185^{* * * *} \\
(2.58)\end{array}$ & $\begin{array}{l}2.770^{* * * *} \\
(2.91)\end{array}$ & $\begin{array}{l}1.751^{*} \\
(1.91)\end{array}$ \\
\hline $\ln ($ assets $)$ & $\begin{array}{l}-0.025 \\
(-1.12)\end{array}$ & $\begin{array}{l}-0.026 \\
(-1.18)\end{array}$ & $\begin{array}{l}-0.519^{* *} \\
(-2.19)\end{array}$ & $\begin{array}{l}-0.470^{* *} \\
(-2.03)\end{array}$ \\
\hline $\ln ($ age $)$ & $\begin{array}{l}-0.037 \\
(-1.29)\end{array}$ & $\begin{array}{l}-0.038 \\
(-1.33)\end{array}$ & $\begin{array}{l}-0.471 \\
(-1.59)\end{array}$ & $\begin{array}{l}-0.479^{*} \\
(-1.66)\end{array}$ \\
\hline Volatility & $\begin{array}{l}-0.858^{* * *} \\
(-4.62)\end{array}$ & $\begin{array}{l}-0.932^{* * *} \\
(-5.13)\end{array}$ & $\begin{array}{l}-16.217^{* * *} \\
(-6.96)\end{array}$ & $\begin{array}{l}-16.988^{\text {*** }} \\
(-7.50)\end{array}$ \\
\hline CEO ownership & . & $\begin{array}{l}1.327^{* * *} \\
(2.81)\end{array}$ & . & $\begin{array}{l}20.085^{* * *} \\
(3.24)\end{array}$ \\
\hline CEO tenure & . & $\begin{array}{l}-0.002 \\
(-0.68)\end{array}$ & . & $\begin{array}{l}-0.012 \\
(-0.45)\end{array}$ \\
\hline CEO equity pay & . & $\begin{array}{l}0.159^{* * * *} \\
(3.01)\end{array}$ & . & $\begin{array}{l}0.955 \\
(1.570)\end{array}$ \\
\hline Observations & 2128 & 2128 & 2128 & 2128 \\
\hline $\operatorname{Adj}-R^{2}$ & 0.30 & 0.32 & 0.19 & 0.20 \\
\hline
\end{tabular}




\section{Table 3: 2SLS Regressions of Firm Performance on Founder-CEO Status: First Stage}

This table reports the first-stage of the two-stage least squares regressions relating firm performance to founder-CEO status for both models (1) and (2) in the text. We instrument founderCEO using dead founders and number of founders. Dead founders is the average of an indicator variable that takes the value of 1 if a given founder is dead as of 1992 and zero otherwise. Number of founders is the total number of founders for each firm. Details on the construction of the instruments are provided in the Appendix. All other data is described in Table 1. The estimation period is 1992-1999. All regressions include year effects and 2-digit SIC industry dummies. $t$-stats (in parentheses).

\begin{tabular}{|c|c|c|}
\hline & \multicolumn{2}{|c|}{$\begin{array}{l}\text { Dependent Variable: } \\
\text { FounderCEO }\end{array}$} \\
\hline Indep. Variables & (I) & (II) \\
\hline Dead founders & $\begin{array}{l}-0.293^{* * *} \\
(-17.16)\end{array}$ & $\begin{array}{l}-0.190^{* * *} \\
(-11.94)\end{array}$ \\
\hline Number of founders & $\begin{array}{l}0.022^{* * *} \\
(4.10)\end{array}$ & $\begin{array}{l}0.022^{* * *} \\
(4.66)\end{array}$ \\
\hline $\ln ($ assets $)$ & $\begin{array}{l}-0.007 \\
(-1.11)\end{array}$ & $\begin{array}{l}0.006 \\
(1.09)\end{array}$ \\
\hline $\ln ($ age $)$ & $\begin{array}{l}-0.500^{* * *} \\
(-6.36)\end{array}$ & $\begin{array}{l}-0.061^{* * *} \\
(-8.62)\end{array}$ \\
\hline Volatility & $\begin{array}{l}0.183^{* * *} \\
(2.83)\end{array}$ & $\begin{array}{l}0.249^{* * *} \\
(4.23)\end{array}$ \\
\hline CEO ownership & . & $\begin{array}{l}1.299^{* * *} \\
(10.39)\end{array}$ \\
\hline CEO tenure & . & $\begin{array}{l}0.012^{* * *} \\
(15.53)\end{array}$ \\
\hline CEO equity pay & . & $\begin{array}{l}0.030^{*} \\
(1.69)\end{array}$ \\
\hline Observations & 2128 & 2128 \\
\hline $\operatorname{Adj}-R^{2}$ & 0.40 & 0.52 \\
\hline
\end{tabular}




\section{Table 4: 2SLS Regressions of Firm Performance on Founder-CEO Status: Second Stage}

This table reports results of regressing firm performance (measured alternatively by $\log Q$ and $R O A$ ) on FounderCEO status. FounderCEO is instrumented with dead founders and number of founders. The first stage regressions are reported in Table 3. Columns I and II report results using $\log Q$ as the performance measure. Columns III and IV report results using $R O A$. For each performance measure, we estimate the empirical model in equations (1) and (2) in the text. All data is described in Table 1 and the Appendix. The estimation period is 1992-1999. All regressions include year effects and 2-digit SIC industry dummies. The estimations correct the error structure for heteroskedasdicity and within-firm correlation using the Huber-White estimator. The bottom row of this Table reports an estimate of the difference between the IV and the OLS coefficients on the founderCEO variable, computed using a Hausman (1978) specification test. $t$-stats (in parentheses).

\begin{tabular}{|c|c|c|c|c|}
\hline \multirow[b]{3}{*}{ Indep. Variables } & \multicolumn{4}{|c|}{ Dependent Variable } \\
\hline & \multicolumn{2}{|c|}{$\log Q$} & \multicolumn{2}{|c|}{$R O A$} \\
\hline & (I) & (II) & (III) & (IV) \\
\hline FounderCEO & $\begin{array}{l}1.096^{* * *} \\
(4.33)\end{array}$ & $\begin{array}{l}1.485^{* * *} \\
(3.63)\end{array}$ & $\begin{array}{l}8.998^{* * *} \\
(3.81)\end{array}$ & $\begin{array}{l}10.843^{* * * *} \\
(2.95)\end{array}$ \\
\hline $\ln ($ assets $)$ & $\begin{array}{l}-0.100 \\
(-0.41)\end{array}$ & $\begin{array}{l}-0.028 \\
(-1.08)\end{array}$ & $\begin{array}{l}-0.410^{*} \\
(-1.73)\end{array}$ & $\begin{array}{l}-0.490^{* *} \\
(-1.96)\end{array}$ \\
\hline $\ln (a g e)$ & $\begin{array}{l}0.052 \\
(1.52)\end{array}$ & $\begin{array}{l}0.087^{* *} \\
(2.05)\end{array}$ & $\begin{array}{l}0.177 \\
(0.53)\end{array}$ & $\begin{array}{l}0.396 \\
(1.01)\end{array}$ \\
\hline Volatility & $\begin{array}{l}-1.196^{* * *} \\
(-4.53)\end{array}$ & $\begin{array}{l}-1.443^{* * *} \\
(-4.44)\end{array}$ & $\begin{array}{l}-18.687^{* * *} \\
(-6.86)\end{array}$ & $\begin{array}{l}-20.558^{* * *} \\
(-6.70)\end{array}$ \\
\hline CEO ownership & . & $\begin{array}{l}-0.547 \\
(-0.56)\end{array}$ & . & $\begin{array}{l}6.981 \\
(0.77)\end{array}$ \\
\hline CEO tenure & . & $\begin{array}{l}-0.020^{* * *} \\
(-3.21)\end{array}$ & . & $\begin{array}{l}-0.141^{* *} \\
(-2.39)\end{array}$ \\
\hline CEO equity pay & . & $\begin{array}{l}0.100 \\
(1.52)\end{array}$ & . & $\begin{array}{l}0.543 \\
(0.78)\end{array}$ \\
\hline Observations & 2128 & 2128 & 2128 & 2128 \\
\hline Diff. IV - OLS & $\begin{array}{l}0.854^{* * *} \\
(8.883)\end{array}$ & $\begin{array}{l}1.300^{* * *} \\
(7.948)\end{array}$ & $\begin{array}{l}6.230^{* * *} \\
(5.345)\end{array}$ & $\begin{array}{l}9.093^{* * *} \\
(4.861)\end{array}$ \\
\hline
\end{tabular}




\section{Table 5: Firm Performance and Founder-CEO Status: Results From Endoge- nous Dummy Variable Model}

This table reports results of regressing firm performance (measured alternatively by $\log Q$ and $R O A$ ) on founder-CEO status. FounderCEO is instrumented with dead founders and number of founders. The estimation method takes the discrete nature of founderCEO explicitly into account. Columns I and II report results using $\log Q$ as the performance measure. Columns III and IV report results using $R O A$. For each performance measure, we estimate the empirical model in equations (3) to (5) in the text. We use the same control variables as in Tables 2 to 4 . All data are described in Table 1 and the Appendix. The estimation period is 1992-1999. All regressions include year effects and 2-digit SIC industry dummies. The estimations correct the error structure for heteroskedasdicity and within-firm correlation using the HuberWhite estimator. The bottom row reports an estimate of the correlation between the error terms of equations (3) and (4) in the text. The P-value is from a Wald test of the independence of equations. $t$-stats (in parentheses).

\begin{tabular}{|c|c|c|c|c|}
\hline \multirow[b]{3}{*}{ Indep. Variables } & \multicolumn{4}{|c|}{ Dependent Variable } \\
\hline & \multicolumn{2}{|c|}{$\log Q$} & \multicolumn{2}{|c|}{$R O A$} \\
\hline & (I) & (II) & (III) & (IV) \\
\hline FounderCEO & $\begin{array}{l}0.436^{* * *} \\
(5.42)\end{array}$ & $\begin{array}{l}0.383^{* * *} \\
(4.53)\end{array}$ & $\begin{array}{l}3.579^{* * *} \\
(3.76)\end{array}$ & $\begin{array}{l}2.514^{* * *} \\
(2.78)\end{array}$ \\
\hline $\ln ($ assets $)$ & $\begin{array}{l}-0.022 \\
(-1.01)\end{array}$ & $\begin{array}{l}-0.023 \\
(-1.08)\end{array}$ & $\begin{array}{l}-0.507^{* *} \\
(-2.17)\end{array}$ & $\begin{array}{l}-0.460^{* *} \\
(-2.02)\end{array}$ \\
\hline $\ln ($ age $)$ & $\begin{array}{l}-0.028 \\
(-1.03)\end{array}$ & $\begin{array}{l}-0.028 \\
(-1.04)\end{array}$ & $\begin{array}{l}-0.430 \\
(-1.50)\end{array}$ & $\begin{array}{l}-0.439 \\
(-1.57)\end{array}$ \\
\hline Volatility & $\begin{array}{l}-0.936^{* * *} \\
(-5.19)\end{array}$ & $\begin{array}{l}-1.012^{* * *} \\
(-5.73)\end{array}$ & $\begin{array}{l}-16.521^{* * *} \\
(-7.28)\end{array}$ & $\begin{array}{l}-17.265^{* * *} \\
(-7.83)\end{array}$ \\
\hline CEO ownership & . & $\begin{array}{l}1.293^{* * *} \\
(2.84)\end{array}$ & . & $\begin{array}{l}19.907^{* * *} \\
(3.27)\end{array}$ \\
\hline CEO tenure & . & $\begin{array}{l}-0.002 \\
(-0.83)\end{array}$ & . & $\begin{array}{l}-0.013 \\
(-0.50)\end{array}$ \\
\hline CEO equity pay & . & $\begin{array}{l}0.150^{* * *} \\
(2.89)\end{array}$ & . & $\begin{array}{l}0.919 \\
(1.54)\end{array}$ \\
\hline Observations & 2128 & 2128 & 2128 & 2128 \\
\hline Correlation estimate & $-0.395^{* * *}$ & $-0.397 * * *$ & $-0.121^{* * *}$ & $-0.112^{* *}$ \\
\hline P-value ind. eqs. & 0.0002 & 0.0003 & 0.0052 & 0.0123 \\
\hline
\end{tabular}




\section{Table 6: Probit Estimates of Founder-CEO Succession}

In this table we examine the effect of lagged performance on the likelihood that a founder retains the CEO title. We restrict our sample to firms that were run by one of their founders in any year in our sample. The dependent variable (Stepout) is a dummy which takes the value of 1 in the firm-years in which a founder-CEO steps out and is 0 otherwise. For each firm that has experienced a change of command in this restricted sample, we leave out all observations in the years after the one in which the founder has relinquished the CEO title. Columns I and III report results using $\log Q$ as the performance measure, and Columns II and IV report results using ROA. The variable high $Q$ is a dummy which is equal to one if the average of the first two lags of $Q$ is at the top quartile of the $Q$ distribution in any firm-year, and is zero otherwise. The variable low $Q$ is a dummy which is equal to one if the average of the first two lags of $Q$ is at the bottom quartile of the $Q$ distribution in any firm-year, and is zero otherwise. The variables highROA and lowROA are constructed in the same way. Lagged $Q$ and laggedROA are the averages of the first two lags of each performance variable. All data are described in Table 1. The estimation period is 1992-1999. All regressions include year effects. The estimations correct the error structure for heteroskedasdicity using the Huber-White estimator. $z$-stats (in parentheses).

\begin{tabular}{|c|c|c|c|c|}
\hline \multirow[b]{2}{*}{ Indep. Variables } & \multicolumn{4}{|c|}{ Dependent Variable: Stepout } \\
\hline & (I) & (II) & (III) & (IV) \\
\hline $\operatorname{High} Q$ & $\begin{array}{l}0.117 \\
(0.67)\end{array}$ & . & $\begin{array}{l}0.594 \\
(1.48)\end{array}$ & . \\
\hline Low $Q$ & $\begin{array}{l}0.311 \\
(1.22)\end{array}$ & . & $\begin{array}{l}0.426 \\
(1.56)\end{array}$ & . \\
\hline HighROA & . & $\begin{array}{l}0.472^{*} \\
(2.48)\end{array}$ & . & $\begin{array}{l}0.862^{* *} \\
(2.32)\end{array}$ \\
\hline LowROA & . & $\begin{array}{l}0.723^{* * *} \\
(3.38)\end{array}$ & . & $\begin{array}{l}0.719^{* * *} \\
(3.21)\end{array}$ \\
\hline LaggedQ $* H i g h Q$ & . & . & $\begin{array}{l}-0.180 \\
(-1.32)\end{array}$ & . \\
\hline Lagged $Q * \operatorname{Low} Q$ & . & . & $\begin{array}{l}-1.892 \\
(-1.13)\end{array}$ & . \\
\hline LaggedROA $*$ HighROA & & . & . & $\begin{array}{l}-0.014 \\
(-1.19)\end{array}$ \\
\hline LaggedROA $*$ LowROA & . & . & . & $\begin{array}{l}-0.002 \\
(-0.21)\end{array}$ \\
\hline Observations & 459 & 466 & 459 & 466 \\
\hline
\end{tabular}

"***,**,* indicate statistical significance at 1\%,5\%, and 10\% (two-tail) test levels, respectively. 


\section{Table 7: Probit Estimates of Founder-CEO Succession with Ownership Con- trols}

In this table we examine the effect of ownership controls on the likelihood that a founder retains the CEO title. We add lagged ownership and two interaction terms between ownership and performance to the specification in column II of Table 6 . We define an indicator variable called highOWNERSHIP which takes the value of 1 if lagged ownership is above 0.05. The estimation period is 1992-1999. All regressions include year effects. The estimations correct the error structure for heteroskedasdicity using the Huber-White estimator. $z$-stats (in parentheses).

\begin{tabular}{|c|c|c|}
\hline \multirow[b]{2}{*}{ Indep. Variables } & \multicolumn{2}{|c|}{$\begin{array}{l}\text { Dependent Variable: } \\
\text { Stepout }\end{array}$} \\
\hline & $(\mathrm{I})$ & (II) \\
\hline HighROA & $\begin{array}{l}0.514^{* * *} \\
(2.62)\end{array}$ & $\begin{array}{l}0.562^{* * *} \\
(2.59)\end{array}$ \\
\hline LowROA & $\begin{array}{l}0.663^{* * *} \\
(3.02)\end{array}$ & $\begin{array}{l}0.554^{* *} \\
(2.19)\end{array}$ \\
\hline Lagged Ownership & $\begin{array}{l}-2.308^{*} \\
(-1.89)\end{array}$ & $\begin{array}{l}-2.243 \\
(-1.34)\end{array}$ \\
\hline HighOWNERSHIP $*$ highROA & . & $\begin{array}{l}-0.151 \\
(-0.44)\end{array}$ \\
\hline HighOWNERSHIP * lowROA & . & $\begin{array}{l}0.356 \\
(0.94)\end{array}$ \\
\hline Observations & 461 & 461 \\
\hline
\end{tabular}

***,**,* indicate statistical significance at $1 \%, 5 \%$, and $10 \%$ (two-tail) test levels, respectively. 